\title{
The Impact of Remittance on the Real Exchange Rate in Ghana
}

\author{
Emmanuel Nketiah $^{1 *}$, Mavis Adjei1, Bekoe Bernard Boamah ${ }^{2}$, Gibbson Adu-Gyamfi ${ }^{1}$ \\ ${ }^{1}$ School of Business, Nanjing University of Information Science \& Technology, Nanjing, China \\ ${ }^{2}$ Business School, Hohai University, Nanjing, China \\ Email:nketiah888@hotmail.com, oseikai@hotmail.com, bekoe92@yahoo.com,ggimagin@gmail.com
}

How to cite this paper: Nketiah, E., Adjei. M., Boamah, B.B. and Adu-Gyamfi, G. (2019) The Impact of Remittance on the Real Exchange Rate in Ghana. Open Journal of Business and Management, 7, 1862-1879.

https://doi.org/10.4236/ojbm.2019.74128

Received: September 10, 2019

Accepted: September 27, 2019

Published: September 30, 2019

Copyright $\odot 2019$ by author(s) and Scientific Research Publishing Inc. This work is licensed under the Creative Commons Attribution International License (CC BY 4.0).

http://creativecommons.org/licenses/by/4.0/

\section{Open Access}

\begin{abstract}
This study examined the impact of remittance on the real exchange rate on Ghana economic performance. The study extracted and used secondary data sources derived from the World Development Indicators (WDI) of the World Bank and Bank of Ghana websites over the period 1970-2016. Trade openness, government public debt, remittance, terms of trade, capital flow were used as independent variable and real exchange rate as the dependent variable. Using the Ordinary Least Squares (OLS) estimator, the study established that government public debt, trade openness and capital flow had significant impact on real exchange rate in Ghana. The study also established that remittance and terms of trade have no significant impact on real exchange rate. The analysis further suggests that, in the long run, a change in the real exchange rate is generally related to movement in economic fundamentals.
\end{abstract}

\section{Keywords}

Remittance, Real Exchange Rate, Capital Flows

\section{Introduction}

Capital inflows play an important part in the economies of developing countries. The major mechanisms of private capital inflows comprise foreign direct investment (FDI), employee's remittances, and portfolio investment. These flows have tremendously increased over the past years and the composition and magnitude of the various capital flows have experienced significant changes over the past decade [1].

The dynamic studies of remittances remain one of the main components of capital flows, and are in advance prominence in the economic literature and economic study [2]. These researches address a wide diversity of issues, stret- 
ching from its microeconomic effect on recipient households to its impact on major macroeconomic variables. Moreover, issues of study interest comprise its role as a cause of foreign exchange; welfare effects; and other concerns regarding its result on inflation and the real exchange rate (RER). Bearing in mind the major attention RER has grown over the past decades as a policy variable, this research seeks to bring out an in-depth analysis of the role of remittances in the real exchange rate dynamics in Ghana. Furthermore, the potential academic contribution is to inform policymakers of the potentially negative implications associated with exchange rate dynamics in Ghana. Also, we analyze the yearly flow of remittances and how it affects exchange rate in Ghana. Furthermore, we investigate how remittances affect the Ghanaian economy.

The dimensions of remittances in the developing world are classified into three parts, of which official development assistance (ODA) is more than other financial inflows [3]. In 2010, the total amount of remittances received by developing countries was estimated at $\$ 320.8$ billion, an increase of more than $400 \%$ above the 2000 value [4]. The design of remittance flows is varied but the regions where receivers of remittances (relative to total output) were highest were North Africa, South Asia, and the Middle East.

There has been a constant increase in the level of remittances to North Africa, South Asia, and the Middle East. Available data prove that Ghana, like any other developing country, has had its fair share of the increase in the flow of remittances. The inflows of remittances to the Ghanaian economy have increased significantly averaging about $\$ 54.5$ million over the past decade compared to $\$ 20.3$ million in the previous decade.

About $\$ 135$ million was recorded in the year 2010. The level of remittance as a portion of Ghana's Gross Domestic Product (GDP) monitored a similar trend. It increased from about $0.2 \%$ of GDP in 2000 to about $1.5 \%$ of GDP in 2010 [4]. Arguably, it is mostly projected that remittances should have a positive effect on the overall economy.

Nonetheless, with the increasing flow of remittances, there is a concern about the potential negative impacts on an economy. Massive volumes of remittances comparative to the size of the economy could have detrimental effects such as high inflation, inefficient resource reallocation, exchange rate appreciation, among others. Researches on Pakistan by Mandelman et al. with respect to the effect of remittance inflows, established the experience of Dutch disease. Extraordinary capital inflows resulted in the real appreciation of the domestic currency that made the export sector less competitive, adversely affecting the economy.

The present study examines the impact of remittance on the real exchange rate on Ghana economic performance. The remaining sections are organized as follows: Section 2 presents the literature review which highlights the concept of remittance and exchange rate, theoretical and empirical framework. The data and methodology are presented enumerated in Section 3, while the results and analysis are shown in Section 4. Finally, summary, conclusion and policy impli- 
cations are presented in Part 5.

\section{Literature Review}

\subsection{Remittances and Exchange Rate}

Research on remittances, particularly in developing countries, have a focus on the significant positive macroeconomic impact on these economies. Remittances to developing countries as posited by Fajnzylber and Lopez [5] leads to an increased pace of growth as well as better well-being and education although such countries are sometimes connected with lower levels of poverty.

Remittance flows to most developing countries are to be countercyclical in the recipient economies as they assist as supplements to household income in periods of low economic activity [3]. Periods of general economic hardships ascending from natural disasters or conflict are usually accompanied with higher inflows of remittances that stabilize as economic conditions improve. Ratha [3] records proof of high remittance flows to the Mexican economy during the financial crisis of 1995, Indonesia and Thailand in 1998. The aftermath of the 2010 earthquake in Haiti also observed a surge in remittances which partly decreased the financial strain that occurred because of the disaster. This pattern of inflows can support smoothen aggregate demand and contribute to economic growth.

The developmental role of remittances is well documented and there is an increasing volume of research in that regard. Not only is this recognized at the research level, the issue of remittances as a developmental tool, as well as its potentially negative consequences, has engaged policymakers and the attention of major financial institutions such as the World Bank and International Monetary Fund (IMF) (see for instance IMF's World Economic Outlook 2005 and the World Bank's Global Economic Prospects (2006)). This has resulted in an increase in discussion and research in an attempt to maximize the potential benefits of remittances to developing countries.

In Ghana, there is a suggestion that supports the development and welfare effects of remittances. Remittances have shown to increase individual welfare substantially and support to minimize the negative economic shocks to recipient households [6]. Addison [7] also documents the potential way remittances can augment performance in the macroeconomic development of Ghana.

Remittances can possibly affect the real exchange rate in three main channels. First, remittances may affect the external equilibrium of the economy by raising the net foreign asset position of the country [8]. For example, the theoretical models of [9] [10] [11] [12] imply that the external equilibrium of the economy will be reached when any current account imbalance is compensated by a sustainable flow of international capital.

In turn, the rate of sustainable capital flows will be a function of the stock of foreign assets and liabilities of the economy, so that changes to the net foreign asset position of the country will lead to changes in the real equilibrium ex- 
change rate.

Second, remittances can also affect the internal equilibrium of the economy in situations where domestic capital and labor are efficiently utilized [8]. A third possibility for remittances to affect the real exchange rate is through their impact on growth [8], although in this case the impact on the exchange rate is likely to be uncertain. However, [8] suggest that indeed remittances appear to lead to a significant real exchange rate appreciation.

Nonetheless, many developing countries that are excessive recipients of capital flows (where remittance is a key component) have to grapple with the impact of these flows on the real exchange rate and the international competitiveness of their exports. Exchange rate stability is a main developmental tool, particularly in countries with highly volatile exchange rate, and has become the main policy issue [13]. Most developing countries detail exchange rate target policies each fiscal year to sustain a stable currency and improve their competitiveness. In Ghana, this reflects every year in the budget statement of the country.

For the developmental impact of a stable exchange rate in mind, much theoretical and empirical research has emerged with the key determinants of the real exchange rate and the factors that cause its volatility being of particular interest. The discussions that follow will give a detailed analysis of some theoretical models and empirical studies that directly inform this study.

\subsection{Theoretical Approaches to Exchange Rate}

Many concepts over the years have shaped today's empirical investigation of the dynamics of the real exchange rate. Numerous researches have used the Purchasing Power Parity (PPP) based approach in trying to model the long run RER dynamics but these systems typically fail to explain the persistent deviation of the RER from its long-run PPP value both in developed and in developing countries [14].

On the other hand, two broad strands of RER models in the literature (the fundamental equilibrium RER (FEER) and the behavioral equilibrium RER (BEER)) that seem to fit the evidence relatively well [15]. Models based on the FEER often specify the path of RER needed to attain both internal and external balance. Thus, in these models, the RER specified as a function of optimum domestic output and sustained capital flows.

However, the FEER approach drops sight of other potentially vital economic fundamentals such as the terms of trade (TOT), openness, trade policy, foreign aid and remittances that also affect the RER. The other approach (BEER), which was invented by [16], uses a single equation reduced form of the behavioral model with an emphasis on variables that affect the relative prices of traded to non-traded goods in the domestic and foreign markets. These variables include medium to long-term economic fundamentals, for instance, the terms of trade, openness, government spending and capital inflows that believed to exert an extensive influence on the RER [15]. This approach takes into account both exter- 
nal and internal factors that play a significant role in RER movement.

\subsection{Empirical Studies on Capital Flows and Exchange Rates-General}

Observed studies on capital flow regularly drawing on the FEER and BEER approach are numerous; they range from the dynamics of capital movement from developed countries (to developing countries) in the form of Aid and Foreign Direct Investment (FDI) to the development impact and growth implication of these flows.

Edwards [17] in a bid to explain exchange rate volatility, built a theoretical model to capture the long run and short run fluctuations of the exchange rate in developing countries. He presented a dynamic small open economy model that sought to explain the effect of both nominal and real variables on the RER. The model argued that equilibrium RER is determined by real variables and that only changes in these variables can affect the long equilibrium RER. His theoretical model was tested using 12 developing countries with data from 1962 to 1985.

His results asserted that nominal variables affect the real exchange rate only in the short run while in the long-run only real variables affect the RER. His findings were consistent with the theoretical presumptions of the BEER approach which asserts that in the long run only fundamentals such as the terms of trade (TOT), capital inflows, technological progress, etc. affect the real exchange rate [18]. His results also supported the opinion that excessively expansionary monetary policy can lead to RER appreciation.

More specifically, [19] confirmed the Dutch disease hypothesis in Pakistan by estimating a linear regression model that included the TOT, government spending, degree of openness, workers' remittances, FDI and foreign economic assistance as explanatory variables for movement in RER. The argument put forward for the inclusion of these variables is that the RER is a function of a set of exogenous and policy-induced fundamentals (in line with BEER).

His model included worker's remittances as a separate explanatory variable due to its importance on the Pakistani economy. He found that increases in all the various forms of capital inflows led to an RER appreciation. His analysis raised important questions regarding the stationary nature of data and the need to resort to alternative approaches in cases where the data observed to be non-stationary.

In terms of the impact of remittances (specifically) on the RER, studies by [8] on selected Latin American countries also suggests that high flows of remittances to these countries causes a significant appreciation of the RER. A similar study by [20] of Latin American countries obtained results consistent with the previous studies and noted that the appreciation of the RER in these countries, as a result of the increased level of remittances, reduced their competitiveness and may have led to a reallocation of resources to the non-tradable sector. Both studies derived their theoretical basis on the single equation reduced form of the behavioral model developed by [16]. 
Most of the observed studies available strongly support the idea that large flows of capital (and remittances) lead to RER appreciation, however, some studies are more less arguable in their conclusion. For instance, while studies by [21] [22] found strong evidence in support of Dutch disease in their empirical studies, [23] and Fayad's [24] indicated that remittances tend to appreciate the RER but only under certain country-specific economic circumstances.

More specifically, Barajas concluded that only countries with more open capital accounts and low levels of trade are likely to experience RER appreciation associated with increased levels of remittances. The most striking revelation of [24] analysis, in relation to those previously mentioned, is that any empirical study on the RER and remittances must take into account the degree of openness of the country's capital account and its level of trade with the rest of the world.

\subsection{Empirical Studies on Capital Flows and Exchange Rates of Ghana}

Various studies in Ghana concerning capital flows and RER differ in their findings. [25] pointed out in his studies that abundant foreign aid in the Ghanaian economy during the period of SAPs led to apparent RER appreciation (reflected by domestic inflation and continuous devaluation of the currency) and the crowding out of the private sector due to government's increased demand for domestic goods and services. Young's analysis was a comprehensive study that observed the pattern of aid flow before and after SAPs and the economic indicators between the two periods to draw his conclusion.

Studies by [26] on Ghana also confirmed that, indeed, capital inflows to the Ghanaian economy tend to cause an appreciation of the real exchange rate. They used the Vector Autoregressive approach to analyze the relationship between a set of variables that included the degree of openness, terms of trade (TOT), total factor productivity and aid as explanatory variables. This study is particularly important because of the exposition on the vital economic variables that affect the RER in Ghana.

However, [27] study on the effect of foreign aid on the RER in Ghana found that, contrary to theoretical predictions, inflows of foreign aid to the Ghanaian economy actually depreciated the RER. This study was done using a co-integration approach and the main variables included in the model are, terms of trade (TOT), Aid, Government expenditure on non-tradable (measured by the share of government spending in GDP), technological progress (proxied by the index of agricultural production), Government's expansionary monetary policy, parallel market premium and change in the nominal exchange rate. This analysis differs from that of [26] in two ways; it does not include the effect of structural breaks and uses the bilateral nominal exchange rate to compute the RER instead of the nominal effective exchange rate used by [26].

\subsection{The Ghanaian Economy: An Overview}

The period immediately after Ghana's independence witnessed a surge in in- 
vestment activities by the government mainly on improving the country's infrastructure. With the availability of funds from the relatively high price of exports during this period (mainly cocoa), the country appeared poised for growth and development. However, high levels of corruption and numerous military interventions from 1966 through to the early 1980's coupled with drought and the subsequent low export prices of its primary commodity exports (cocoa and gold) resulted in the fading of the country's economic fortunes.

With the abysmal performance of the economy following this period, the country succumbed to the IMF and World Bank sponsored structural adjustment intervention programs. The ultimate motive was to secure funds and developmental aid to reposition the country towards a trajectory of sustained growth and development. The Economic Recovery Program (ERP) of 1983 was the premier intervention program. Since the implementation of the Structural Adjustment Program (SAP), the country has made significant strides in enhancing socio-economic development and industrial capacity [28].

GDP growth rate (a) has been steady over several decades moving upward and inward starting from the year 1984 to 2016. However, the country recorded an unprecedented growth rate of $14 \%$ in 2011 . This growth rate witnessed in the country is likely the result of major policy initiatives undertaken by government to promote the private sector and improve the business environment that are beginning to yield positive results (Figure 1 ).

The average growth rate (b) between the years $1970-1983$ is $14 \%$. In addition, 1983-1996 recorded 13\%, 13\% also for 1996-2009 and 7\% for 2009-2016. In terms of monetary policy, the Bank of Ghana is doing considerably well in pursuing sound monetary policies. In addition, this is manifested in the steady decline in inflation and the improved macroeconomic environment that has boosted investor confidence and attracted substantial amount of foreign direct investment into the country [29].

Some economists have questioned the over restrictive inflation targeting policy pursued by the Bank of Ghana and recommend monetary policies that are geared towards promoting growth and employment along with maintaining moderate levels of inflation [30]. This highlights the fact that the central bank
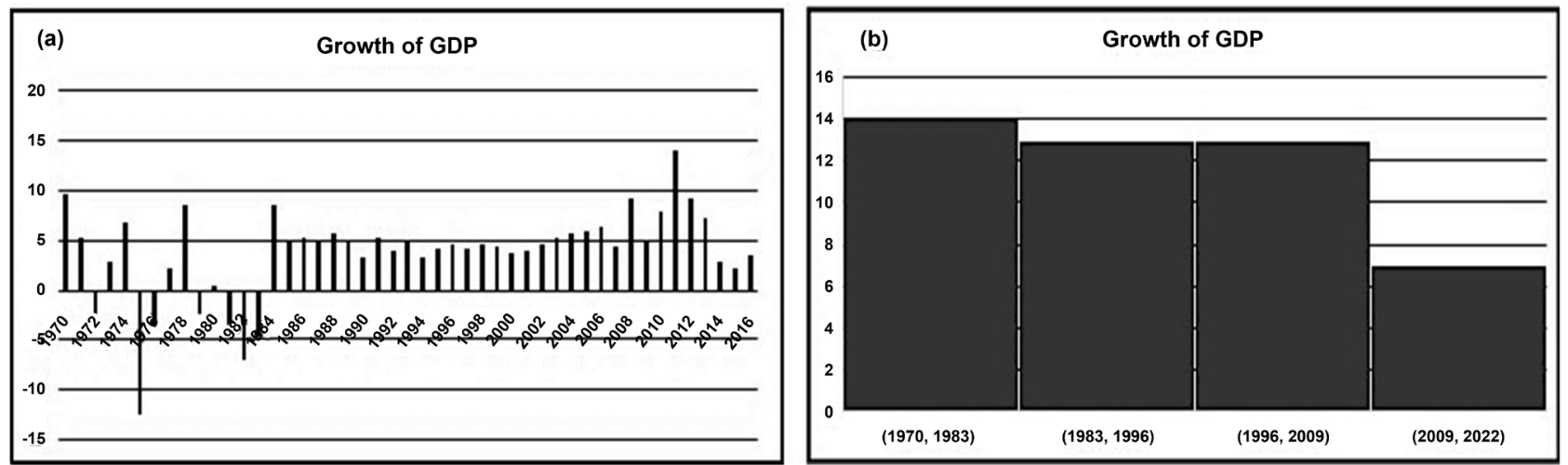

Figure 1. Average value of GDP (a) and (b). 
still has an important role to play in the success and the building of a resilient economy.

\section{Real Exchange Rate (RER)}

\subsection{Real Exchange Rate (RER) Trend in Ghana}

Theoretically, there are several ways of measuring the RER. One commonly used measure is the relative price of tradable to non-tradable goods. Another measure of the RER uses the ratio of a unit cost of labor in the foreign country to that in the home country expressed in a common denominator (using the nominal exchange rate) as a measure of the RER.

However, these are usually difficult to estimate over time because of limited data availability. A more practical approach is to use the nominal exchange rate adjusted for the relative price differences between the relevant country and the rest of the world [19]. Thus, here we use the US wholesale price index (WPI) relative to the consumer price index (CPI) of Ghana as the measure of RER as indicated by the following

$$
\mathrm{RER}=\mathrm{ER} * \mathrm{WPI}
$$

where ER is the nominal exchange rate. WPI is wholesale price index.

In the formulation above, an increase in the ratio represents RER depreciation whiles a decrease indicates an appreciation.

As Figure 2 indicates, the real exchange rate (RER) (a) and (b). The RER (b) (based on the above measure) was stable from 1998 to 2016 after which it depreciated against the dollar and peaked in 2000. It again appreciated in 2006 and remained stable until 2008. It then depreciated in the year 2014. 1998 recorded the highest within the sample period. It has, steadily depreciated from 2000 with little deviation from that trend.

\subsection{Remittance Inflow}

Apparently shown in Figure 3, the remittance inflow (based on the above measure) was stable from 1987 to 2010 after which it depreciated against the dollar
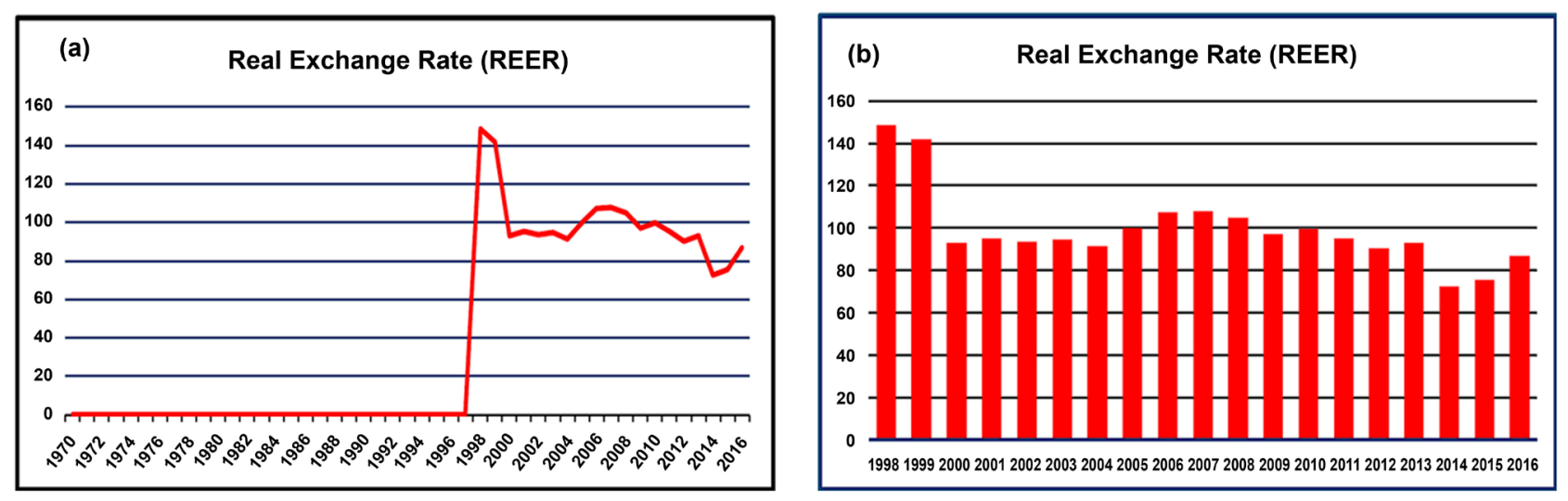

Figure 2. The RER for Ghana from 1970-2016 and (b) the RER for Ghana from 1998-2016. 


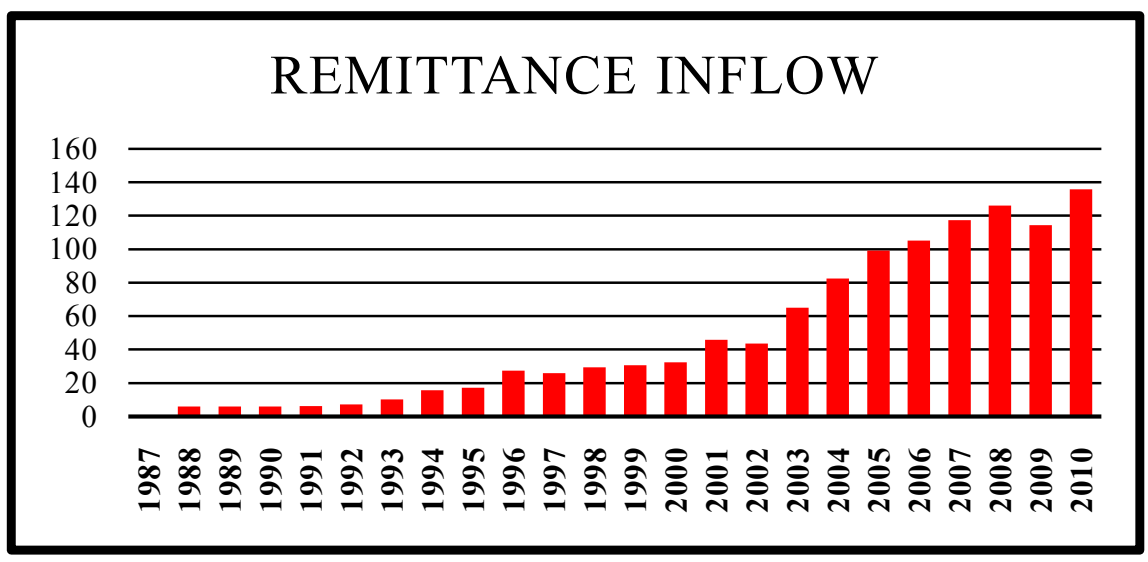

Figure 3. The REMITT for Ghana from 1987-2010.

and peaked in 1988. It again appreciated in 1996 and remained stable until 2000. It then depreciated in the year 2002, appreciated again from 2003 to 2008 and also depreciated in the year 2009. It then appreciated in the year 2010, the highest within the sample period.

\section{Real Exchange Rate and Fundamentals}

Following the earlier discussion on the theoretical approaches to RER, we use the BEER approach because of its wide usage and relative ease of applicability in empirical studies of the RER; especially in developing countries as adopted in [15] and [20]. According to this model, several fundamentals determine the movement of real exchange rate across countries. [26] provides details of the important macroeconomic variables that determine the real exchange rate of Ghana.

Here we give a brief description of these variables and shows how they affect the real exchange rate. In addition, this chapter analyses the data and presents results gained from the assessment of the model. The analyzed data are presented in graphs and tables.

\subsection{Terms of Trade (TOT)}

Measured as the relative price of exports to imports, the terms of trade measures the effect of external demand and supply on the tradable sector of an economy. Movements in the TOT result in two effects (i.e. the substitution and income effect) and these have different impacts on the RER. The income effect of an improvement in the TOT is that more money being spent on both tradable and non-tradable goods in the economy. This results in an increase in the price level in the non-tradable sector and lead to RER appreciation.

The substitution effect is that more imports would lead to the detriment of domestic goods, which causes a drop-in demand of non-tradable goods resulting in a decline of their prices and RER depreciation. Thus, it is difficult to determine which of the two effects on the RER dominates the other. 


\subsection{Trade Openness (OPEN)}

The level of openness of an economy also has a significant effect on the movement of the RER. It usually measures the degree to which an economy engages in international transactions. Trade restrictions through policies such as quotas and tariffs usually result in an increase in the prices of both imports and non-tradable goods leading to an appreciation of the currency.

A more liberalized economy benefits from international competitiveness and technological transfer, which lead to lower prices in the non-tradable sector and result in RER depreciation. Owing to the unavailability of data, specifically on trade restriction and international openness, one popular measure used in the literature [19] and [31] as a proxy for the degree of liberalization is the ratio of imports plus exports to GDP.

\subsection{Capital Flows}

Theoretically, all forms of capital inflows expected to result in RER appreciation. However, empirical estimates suggest that the impact of the various types of capital inflows on the RER depends on the degree of reversibility of that particular component which varies from one economy to the other. For the purpose of this study, we disaggregate the flows of capital into two main components.

Using the above variables, noted to have a significant influence on the RER, we proceed to estimate the following regression equation directly in line with that specified by [19].

\section{Data and Methodology}

\subsection{Data Collection}

Annual time series data on Ghana from 1970 to 2016, drawn from the World Bank's World Development indicators (WDI) were used in order to achieve the objectives of the study. The reason for selecting the period was based on data availability. To get a better view, the study includes foreign direct investment (FDI), Economic growth (as a proxy by real GDP). OPEN measures the extent of openness of the economy measured as the sum of exports and imports (Trade) as a percentage of GDP.

The current account is the balance of trade between a country and its trading partners. A ratio comparing export prices to import prices, the terms of trade (TOT) related to current accounts and the balance of payments. Foreign investors inevitably seek out stable countries with strong economic performance in which to invest their capital.

In this section, descriptive statistics (i.e. means, standard deviations, minimum and maximum values of variables) and diagnostic testing based on test for multi collinearity and Pearson correlation were implemented for the research study. Multicollinearity on regression estimates to assess the effects of different degrees of multicollinearity following [32].

The null hypothesis was no multicollinearity on regression estimates. The fol- 
lowing studies have used this type of techniques [33]. Also, to examine the relationship among the variables, Pearson correlation test was conducted. The null hypothesis is that there is no relationship between real exchange rate and the explanatory variables. Pearson correlation test has been applied by the following studies.

\subsection{Modelling}

\section{Empirical Estimation Model}

The basic form of the model used is

$$
y=m x+c
$$

Consider a hypothetical data set $\left(x_{1}, x_{2}, x_{3}, x_{n}, y\right)$, and a hypothesized linear regression model

$$
y_{1}=\beta_{0}+\beta_{1} x_{1 i}+\beta_{2} x_{2 i}+\cdots+\beta_{n} x_{n i}+\varepsilon_{i}
$$

The study used the determinants of the real exchange rate in Ghana focusing on developing a simple real exchange rate model for Ghana in Equation (3) below; real exchange rate (REER), trade openness (OPEN government public debt (PUBLIC), remittance (REMITT), capital flow (CAPTINF) AND term of trade (TERMTRAD)

$$
\begin{aligned}
\operatorname{REER}_{t}= & \delta_{o}+\delta_{i} \mathrm{OPEN}_{t}+\delta_{i} \mathrm{PUBLIC}_{t}+\delta_{i} \mathrm{REMITT}_{t} \\
& +\delta_{i} \mathrm{CAPTINF}_{t}+\delta_{i} \mathrm{TERMTRAD}_{t}+\cdots+u_{t}
\end{aligned}
$$

\subsection{Results and Analysis}

Table 1 presents the outcome of the estimation in which the results are based on mean, standard deviation, minimum, maximum for the selected dependent an independent variable.

Figure 4 shows the time series plot for natural logarithm transformation(a) and the time series plot for first difference transformation (b) of real exchange rate (REER), trade openness (OPEN government public debt (PUBLIC), remittance (REMITT), capital flow (CAPTINF) AND term of trade (TERMTRAD) from 1970-2016 based on STATA output. All variables were transformed into natural logarithms.

When a multicollinearity diagnostic is considered, pairwise correlation coefficients between predictors and VIF are the most common tools for inspection

Table 1. Descriptive Statistics for selected dependent and explanatory variables.

\begin{tabular}{cccccc}
\hline Variable & Observations & Mean & Standard deviation & Minimum & Maximum \\
\hline REER & 47 & 40.178 & 50.641 & 0.000 & 148.578 \\
REMITT & 47 & 459.769 & 1359.99 & 0.000 & 7589.549 \\
PUBLIC & 47 & 10.699 & 2.083 & 5.861 & 15.308 \\
OPEN & 47 & 55.861 & 28.72904 & 6.320 & 116.048 \\
CAPTINF & 47 & 2.215 & 2.965 & -0.660 & 9.545 \\
TERMTRAD & 47 & -8.684 & 7.511 & -25.273 & 5.506 \\
\hline
\end{tabular}



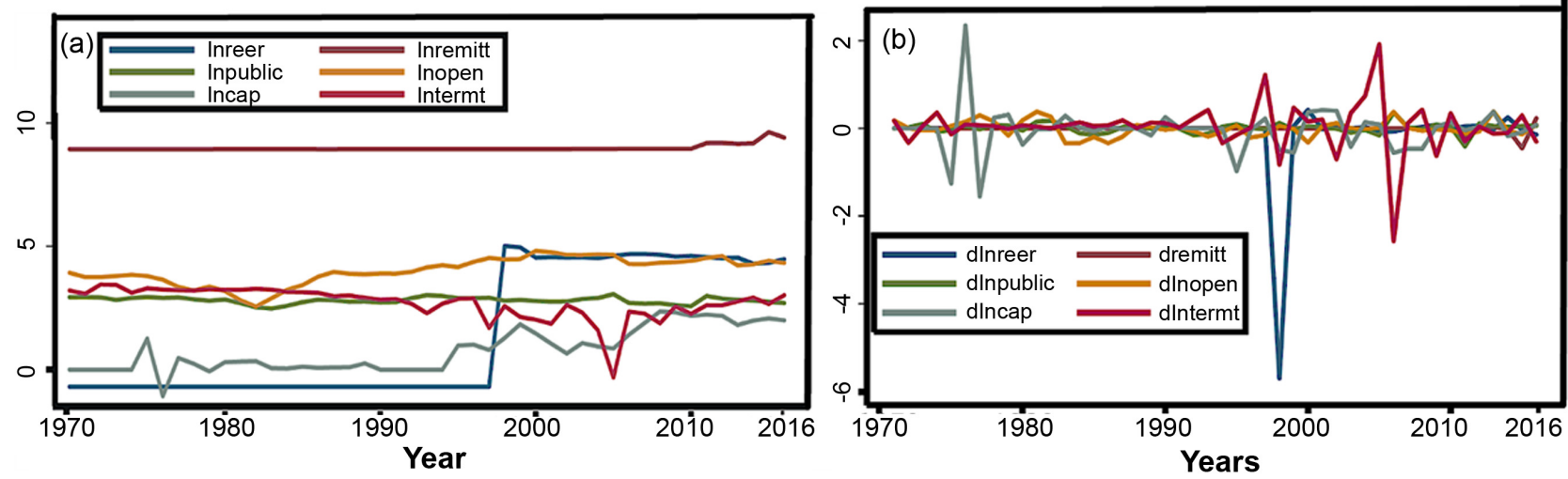

Figure 4. (a) ADF test at levels from the year 1970 to 2016; (b) ADF test at first difference from 1970-2016.

used by statisticians and epidemiologists. Some investigators use correlation coefficients cut-offs of 0.5 and above [34] but most typical cut-off is 0.80 [35]. Although VIF greater than 5 or VIF greater than 10 [31]. are suggested for detecting multicollinearity, there is no universal agreement as what the cut-off based on values of VIF should be used to detect multicollinearity. If the VIF is greater than 10 , then there exist multicollinearity and vice versa. The results showed that the null hypothesis is rejected, which means that there is no evidence of multicollinearity (Table 2).

The null hypothesis is that there is no relationship between real exchange rate and the explanatory variables.

The results from Table 3 show that terms of trade (TERMTRAD) have a moderately negative $(\mathrm{P}=6.98)$ with real exchange rate. The negative relationship indicates that an increase in trade openness decreases real exchange rate. The negative sign is expected because theoretically, the more opened an economy the higher the rate at which the real exchange rate will depreciate. The remaining variables showed weak relationship with real exchange rate. For example, trade openness and cash flow showed very weak but positive relationship with real exchange rate. There is a weak and a negative relationship between real exchange rate and public debt. The reason is that a large debt encourages inflation, and if inflation is high, the debt will be serviced and ultimately paid off with cheaper real dollars in the future.

\section{Regression Result Analysis}

Table 4 shows the regression coefficients for the model estimating the impact of selected factors on real exchange rate using Pooled OLS. From the Table, the model shows that capital flow (CAPTINF), Government public debt (PUBLIC) and trade openness (OPEN) were significant at 5\% level in Pooled OLS estimation. This suggests that capital flow, government public debt and open are good explanatory variables for determinants of real exchange rate in Ghana. The coefficients on the explanatory variables are negative (except OPEN and CAPTINF) and shown in Equation (7).

The model for the REER 
Table 2. Multicollinearity results for all variables.

\begin{tabular}{ccc}
\hline Variable & VIF & $1 /$ VIF \\
\hline OPEN & 4.40 & 0.227 \\
TERMTRAD & 3.82 & 0.262 \\
CAPTINF & 2.16 & 0.463 \\
REMITT & 1.50 & 0.669 \\
PUBLIC & 1.28 & 0.782 \\
REER & & \\
Mean VIF & & 2.63 \\
\hline
\end{tabular}

Table 3. Pearson correlation among explanatory variables used in the regression analysis.

\begin{tabular}{ccccccc}
\hline Variables & REER & REMITT & PUBLIC & OPEN & CAPTINF & TERMTRAD \\
\hline REER & 1.000 & & & & & \\
REMITT & 0.292 & 1.000 & & & & \\
PUBLIC & -0.151 & -0.066 & 1.000 & & & \\
OPEN & 0.767 & 0.229 & 0.210 & 1.000 & & \\
CAPTINF & 0.738 & 0.517 & -0.227 & 0.5246 & 1.000 & \\
TERMTRAD & -0.698 & -0.073 & -0.102 & -0.843 & -0.462 & 1.000 \\
\hline
\end{tabular}

Table 4. Regression coefficients for the model estimating the determinants of real exchange rate in Ghana using Pooled Least Squares (OLS).

\begin{tabular}{ccccc}
\hline REER & Coefficient & Standard Error & t-statistic & P value $(\mathrm{P}<0.05)$ \\
\hline C & 15.749 & 20.891 & 0.75 & 0.455 \\
REMITT & -0.002 & 0.003 & -0.69 & 0.497 \\
PUBLIC & -4.453 & 2.017 & -2.21 & $0.033^{*}$ \\
OPEN & 0.951 & 0.271 & 3.51 & $0.001^{*}$ \\
CAPTINF & 7.002 & 1.841 & 3.80 & $0.000^{*}$ \\
TERMTRAD & -0.512 & 0.967 & -0.53 & 0.599 \\
Adjusted R-squared & & & 0.752 & \\
R-squared & & 0.779 & \\
F-statistic & & 28.95 & \\
Prob (F-statistic) & & 0.00 & \\
No of observations & & 47 & \\
r & & &
\end{tabular}

*Significance level at 95\% Source Authors construct.

$$
\begin{aligned}
\operatorname{REER}_{t}= & 15.749-0.002 \mathrm{RMITT}_{t}+0.951 \mathrm{OPEN}_{t}-4.453 \mathrm{PUBLIC}_{t} \\
& +7.002 \mathrm{CAPTINF}_{t}-0.512 \mathrm{TERMTRAD}_{t}+\varepsilon_{t}
\end{aligned}
$$

The study uses the Robust Regression test to find out whether the results are robust or not. Table 5 presents the results of the robustness check of this research. 
Table 5. Robust regression test.

\begin{tabular}{|c|c|c|c|c|c|c|}
\hline REER & COEF. & ROBUST. ERR & $\mathrm{T}$ & $\mathrm{P}>\mathrm{T}$ & $95 \%$ CONF & INTERVAL \\
\hline REMITT & -0.001 & 0.003 & -0.69 & 0.497 & -0.009 & 0.005 \\
\hline PUBLIC & -4.453 & 2.017 & -2.21 & 0.033 & -8.526 & -0.381 \\
\hline OPEN & 0.952 & 0.271 & 3.51 & 0.001 & 0.404 & 1.500 \\
\hline CAPTINF & 7.002 & 1.841 & 3.80 & 0.000 & 3.283 & 10.721 \\
\hline TERMTRAD & -0.512 & 0.967 & -0.53 & 0.599 & -2.465 & 1.440 \\
\hline CONS & 15.749 & 20.891 & 0.75 & 0.455 & -26.443 & 57.940 \\
\hline & & $\begin{array}{r}\text { NUMB } \\
\mathrm{F}(5 \\
\text { PRO } \\
\text { R-sq } \\
\text { Adj R-s } \\
\text { Root }\end{array}$ & $\begin{array}{l}\text { OF OB } \\
=123, \\
\mathrm{~F}=0.0 \\
\mathrm{ed}=0.7 \\
\operatorname{ared}= \\
\mathrm{E}=25\end{array}$ & & & \\
\hline
\end{tabular}

In order for the results to be robust, standard error, $\mathrm{R}^{2}$ and adjusted $\mathrm{R}^{2}$ must not reduce significantly. It is very clear in the above table that the $\mathrm{P}$ value is significant at 0.000 . The $R^{2}$ and adjusted $R^{2}$ have not been significantly reduced, indicating that this model still fits well. This means that the results of this study are robust, and the data does not consist of any outliers or contamination.

\section{Summary, Conclusion and Policy Implication}

\subsection{Summary and Conclusion}

Migrants send money back home for the benefit of their families and in some cases to finance business projects left behind. Remittances serve as a source of livelihood for many families in Ghana. What is least thought about is that the increasing flows of remittances into the country, even though beneficial, may have negative consequences on the economy as a whole. The study examines the impact of remittance on the real exchange rate in Ghana (i.e. real exchange rate) and the factors that influence its fluctuations. The impact of remittance on the real exchange rate in Ghana has been one of the contagious issues faced by the various governments since independence.

The study analyzed the behavior of the foreign exchange market, the relationship between the foreign exchange market and its theoretical determinants. The importance of foreign exchange market was briefly reviewed in this study and is well known in the literature for both developed and developing economies. Based on an extensive review of the literature on the determinants of the foreign exchange market, the background of the foreign exchange market system in Ghana and on data availability, an empirical model that links the foreign exchange market to its potential determinants was specified. The variables used for the analyses were capital flow (CAPTINF), government public debt (PUBLIC), trade openness (OPEN) remittance and terms of trade (TERMTRAD).

To analyze the determinants of real exchange rate in Ghana, the Ordinary 
Least Square method was chosen to the other techniques, because of its several advantages over those alternative techniques. In the application of methodology, the study started by analyzing the time series of the data employing both Correlation and Multicollinearity tests as well as overall significance of the model. The variables were found to possess a very low degree of collinearity. The correlation results showed that only a few variables (trade openness public debt and capital flow) correlated moderately with real exchange rate whereas the remaining showed weak correlation with real exchange rate.

The overall significance tests on the other hand show that F-test and adjusted $\mathrm{R}$-squared in the model specifications provided evidence that the explanatory variables are jointly not equal to zero and therefore indicating a good fit of the model. These findings, therefore, depict that foreign exchange rate is subject to changes as a result of changes in the explanatory variables. The variable that has a long run relationship with the exchange rate was trade openness, public debt and capital flow.

This means that increase in trade openness, public debt and capital flow is associated with a real appreciation of the exchange rate in Ghana. These results, therefore, support both the theoretical predictions and empirical results. In the analysis above, it has been established that remittance inflows to Ghana, like most other capital flows, is coincidence with an appreciation of the RER. This has the potential of making the export sector less competitive and this negatively affects production in the sector thus leading to Dutch disease. The paper further revealed that, trade openness (OPEN), public debt (PUBLIC) and capital flow (CAPTINF) in the long run, result in the appreciation of the real exchange rate RER in the Ghanaian economy.

The paper further revealed that, trade openness (OPEN government public debt (PUBLIC) and capital flow (CAPTINF) in the long run, result in the appreciation of the RER in the Ghanaian economy. The analysis raises several important issues: the need to clearly understand the economic importance of remittances in the Ghanaian economy and in particular, the need for a careful study of the consequences on the export sector as a result of REER appreciation resulting from the increasing flows of remittances. The level of remittances to Ghana has increased quite considerably in the last decade and this presents new opportunities as well as challenges. Though the intentions of most migrant remittances may be altruistic, large flows of remittances may have unintended consequences on the whole economy.

\subsection{Policy Implications}

The study used an OLS model to perform modeling real exchange rate against capital flow (CAPTINF), government public debt (PUBLIC), trade openness (OPEN), remittance (REMITT) and terms of trade (TERMTRAD), and the mean equation of the model was robust for modelling real exchange rate. Similarly, the OLS model was found to be a good for modeling volatility and fore- 
casting real exchange rate. Also, the research work has revealed that, the health of Ghana's economy is highly dependent on the strength of the Ghanaian currency: cedi against the foreign currencies since the country is import dependent, as such there must be a national agenda to increase foreign inflows and that introduction of several policies and interventions. Furthermore, the forecast is an indication that policy makers and industry players can effectively plan to curb uncertainties in the Ghanaian economy given these models are used. There must be a national consensus to reduce imports into the country by improving production and in the long run increase non-traditional exports. Last but not least, other economic indicators such as money supply, balance of payment and budget deficit could be added to inflation rate, exchange rate and interest for modelling using other regressions methods.

\section{Acknowledgements}

We extend our special thankfulness to the developers, managers and funding agencies of World Bank Development indicators (WDI) for granting access to these essential datasets in accordance to their specific data use and citation policies.

\section{Conflicts of Interest}

The authors declare no conflicts of interest regarding the publication of this paper.

\section{References}

[1] Ibhagui, O.W. (2019) The Economic Performance Effects of Capital Flows in OPEC Member Countries. The Quarterly Review of Economics and Finance, In Press. https://doi.org/10.1016/j.qref.2019.05.015

[2] Joseph, D.N. (2017) Remittances and Economic Growth: Empirical Evidence from Ghana. European Journal of Business and Management, 6, 142-150.

[3] Ratha, D. (2007) Leveraging Remittances for Development. Policy Brief, 6-7.

[4] World Bank (2011) General Principles for Credit Reporting. World Bank, Washington DC. https://openknowledge.worldbank.org/handle/10986/12792

[5] Fajnzylber, P., López, J.H. and World Bank (2007) Close to Home: The Development Impact of Remittances in Latin America the International Bank for Reconstruction and Development.

[6] Quartey, P. (2006) The Impact of Migrant Remittances on Household Welfare in Ghana African Economic Research Consortium (AERC)

[7] Addison, E.K.Y. (2004) The Macroeconomic Impact of Remittances.

[8] Lopez, H., Bussolo, M. and Molina, L. (2007) Remittances and the Real Exchange rate. World Bank Policy Research Working Paper No. 4213. https://doi.org/10.1596/1813-9450-4213

[9] Mussa, M. (1984) The Theory of Exchange Rate Determination. In Bilson, J.F.O. and Marston, R.C., Eds., Exchange Rate Theory and Practice, University of Chicago Press, Chicago, 13-78. http://www.nber.org/books/bils84-1

[10] Frenkel, J.A. and Mussa, M.L. (1985) Asset Markets, Exchange Rates and the Bal- 
ance of Payments. In: Jones, R.W. and Kenen, P.B., Eds., Handbook of International Economics, Volume II, Elsevier Science Publishers B.V., Amsterdam, 679-747. https://doi.org/10.1016/S1573-4404(85)02005-6

[11] Alberola, E. and López, H. (2001) Internal and External Exchange Rate Equilibrium in a Cointegration Framework. An Application to the Spanish Peseta. Spanish Economic Review, 3, 23-40. https://doi.org/10.1007/PL00013583

[12] Alberola, E. (2007) Misalignment, Liabilities Dollarization and Exchange Rate Adjustment in Latin America. Banco de España Research Paper No. WP-0309. https://doi.org/10.2139/ssrn.981338 https://ssrn.com/abstract $=981338$

[13] Gala, P. (2008) Real Exchange Rate Levels and Economic Development: Theoretical Analysis and Econometric Evidence. Cambridge Journal of Economics, 32, 273-288. https://doi.org/10.1093/cje/bem042

[14] Mussa, M. (1986) Nominal Exchange Rate Regimes and the Behavior of the Real Exchange Rate: Evidence and Implications. Carnegie-Rochester Conference Series on Public Policy, 25, 117-214. https://doi.org/10.1016/0167-2231(86)90039-4

[15] Elbadawi, A.I. and Soto, R. (2005) Theory and Empirics of Real Exchange Rate in Sub-Saharan Africa and Other Developing Countries. World Bank, Mimeo.

[16] Clark, P. and MacDonald, R. (1999) Exchange Rates and Economic Fundamentals: A Methodological Comparison of BEERs and FEERS. In: Stein, J. and MacDonald, R., Eds., Equilibrium Exchange Rates, Kluwer, Boston, MA, 285-322. https://doi.org/10.1007/978-94-011-4411-7_10

[17] Edwards, S. (1989) Real Exchange Rates, Devaluation, and Adjustment: Exchange Rate Policy in Developing Countries. MIT Press, Cambridge, MA.

[18] Engel, C., Mark, N.C. and West, K.D. (2007) Exchange Rate Models Are Not as Bad as You Think. NBER Working Paper No. 13318. https://doi.org/10.3386/w13318

[19] Ahmed, H. (2009) Capital Flows and Real Exchange Rate Overvaluation-A Chronic Ailment: Evidence from Pakistan. Lahore Journal of Economics, 14, 51-81. https://doi.org/10.35536/lje.2009.v14.isp.a4

[20] Amuedo-Dorantes, C. and Pozo, S. (2004) Workers' Remittances and the Real Exchange Rate: A Paradox of Gifts. World Development, 32, 1407-1417. https://doi.org/10.1016/j.worlddev.2004.02.004

[21] Acosta, P.A., Lartey, E.K.K. and Mandelman, F.S. (2009) Remittances and the Dutch Disease. Journal of International Economics, 79, 102-116. https://doi.org/10.1016/j.jinteco.2009.06.007

[22] Holzner, M. (2006) Real Exchange Rate Distortion in Southeast Europe.

[23] Barajas, A. (2010) Workers' Remittances and the Equilibrium Real Exchange Rate: Theory and Evidence. International Monetary Fund.

[24] Fayad, G. (2010) Remittances and Dutch Disease: A Dynamic Heterogeneous Panel Analysis on the Middle East and North Africa Region. Centre for the Study of African Economies (CSAE).

[25] Younger, S.D. (1992) Aid and the Dutch Disease: Macroeconomic Management When Everybody Loves You. World Development, 20, 1587-1597. https://doi.org/10.1016/0305-750X(92)90016-O

[26] Opoku-Afari, M., Morrissey, O., Lloyd, T. and University of Nottingham (2004) Real Exchange Rate Response to Capital Inflows: A Dynamic Analysis for Ghana Centre for Research in Economic Development and International Trade. University of Nottingham, Nottingham. 
[27] Sackey, H.A. (2001) External Aid Inflows and the Real Exchange Rate in Ghana African Economic Research Consortium.

[28] Anyinam, C. (1994) Spatial Implications of Structural Adjustment Programmes in Ghana. Tijdschrift voor economische en sociale geografie, 85, 446-460. https://doi.org/10.1111/j.1467-9663.1994.tb00703.x

[29] Yvonne, M. (2010) Economics, Ghana: Annual Economic Outlook. The Eve of Oil Production. Standard Bank Report.

[30] Epstein, G. and Heintz, J. (2006) Monetary Policy and Financial Sector Reform for Employment Creation and Poverty Reduction in Ghana. International Poverty Center, UNDP.

[31] Semančíková, J. (2016) Trade, Trade Openness and Macroeconomic Performance. Procedia-Social and Behavioral Sciences, 220, 407-416. https://doi.org/10.1016/j.sbspro.2016.05.515

[32] Kutner, M.H., Nachtsheim, C.J. and Neter, J. (2004) Applied Linear Regression Models. 4th Edition, McGraw-Hill Irwin, New York.

[33] Vatcheva, P., and Lee, M. (2016) Multicollinearity in Regression Analyses Conducted in Epidemiologic Studies. Epidemiology: Open Access, 6, 227. https://doi.org/10.4172/2161-1165.1000227

[34] Donath, C., Grässel, E., Baier, D., Pfeiffer, C., Bleich, S., et al. (2012) Predictors of Binge Drinking in Adolescents: Ultimate and Distal Factors-A Representative Study. BMC Public Health, 12, 263. https://doi.org/10.1186/1471-2458-12-263

[35] Berry, WD. and Feldman, S. (1985) Multiple Regression in Practice (Quantitative Applications in the Social Sciences). SAGE Publications, Thousand Oaks, CA. 